\title{
Voorwoord tot die T.F.J. Dreyer Huldigingsbundel
}

\begin{abstract}
Author:
Daan J.C. van Wyk $^{1}$ (jr)

Affiliation:

${ }^{1}$ Moderator of the 69th General Assembly of the Netherdutch Reformed Church of Africa, Pretoria, South Africa

Correspondence to: Daan van Wyk (jr)

Email:

andries.vanaarde@up.ac.za

Postal address:

The Moderator, Netherdutch Reformed Church of Africa, PO Box 2368, Pretoria 0001 , South Africa

How to cite this article: Van Wyk, D.J.C. jr, 2011, 'Voorwoord tot die T.F.J. Dreyer Huldigingsbundel', HTS Teologiese Studies/ Theological Studies 67(3), Art. \#1174, 2 pages. http:// dx.doi.org/10.4102/hts. v67i3.1174
\end{abstract}

C 2011. The Authors. Licensee: AOSIS OpenJournals. This work is licensed under the Creative Commons Attribution License.

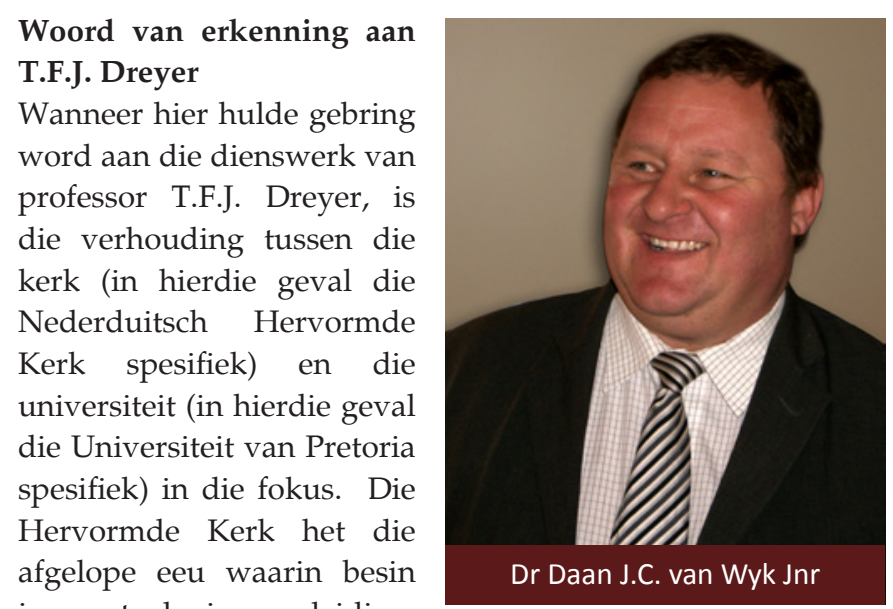

Word of acknowledgement to T.F.J. Dreyer

In a tribute to the work of service of Professor T.F.J. Dreyer, the focus is on the relationship between the church (in this case the Netherdutch Reformed Church specifically) and the university (in this case the University of Pretoria). During the past century, during which a great amount of reflection on theological training has taken place, the Reformed Church has put high value on theological is oor teologiese opleiding, hoë waarde geheg aan 'n teologiese opleiding aan ' $n$ universiteit. Hierdie verhouding moet terselfdertyd akademies uitnemend as kerklik diensbaar en lojaal wees. Dit moet daarom iets reflekteer van die spanning tussen wetenskap en geloof, kansel en kateder.

Professor Dreyer het die afgelope sowat drie dekades ' $n$ besondere rol gespeel om die Hervormde Kerk se verstaan van sódanige teologiese opleiding aan die Universiteit van Pretoria te vestig en te bestendig. Aan die een kant is hy teoloog by uitnemendheid. Hy het verskeie artikels in geakkrediteerde akademiese tydskrifte gepubliseer en talle in populêr-wetenskaplike tydskrifte en koerante. Twee boeke het onder sy naam verskyn en hy het in etlike boeke as medewerker opgetree. Dit is duidelik dat hy met gemak op die verskillende terreine van die Praktiese Teologie beweeg. Sy intellek, belesenheid en akademiese vermoëns stel hom egter in staat om nie net op die terrein van die Praktiese Teologie nie, maar wyd buite sy eie vakgebied die teologiese diskoers te voer en met gesag te praat.

Aan die ander kant is Theuns Dreyer kerkman. Hy is as kerkleier wyd in die Hervormde Kerk en daarbuite bekend. Vanuit sy ouerhuis waar hy as een van vyf predikante broers opgegroei het, ontwikkel hy uitsonderlike kennis van die Hervormde Kerk en 'n diep aanvoeling en liefde vir die teologie en etos van die Kerk. Hy dien vir 21 jaar lank as kerkleier op die Kommissie van die Algemene Kerkvergadering. In dié tyd dien hy vir drie termyne as voorsitter van die Kommissie. As voorsitter het hy ' $n$ besondere rol in die training at university level. This relationship between the church and the university should simultaneously be academically excellent as well as ecclesiastically subservient and loyal. It should therefore reflect something of the tension between science and faith, the pulpit and the lectern.

Professor Dreyer played a significant role over the past three decades to establish and consolidate the Reformed Church's understanding of such theological training at the University of Pretoria. On the one hand, he is a theologian par excellence. $\mathrm{He}$ has published various articles in accredited academic journals and many more in popular scientific magazines and newspapers. $\mathrm{He}$ published two books and co-authored several others. It is clear that he moves with ease within the various areas of Practical Theology and his intellect, wide reading and academic capabilities enable him not only to participate in the theological discourse, to be an authoritative voice in these areas, but also outside his field of study.

On the other hand, Theuns Dreyer is a clergyman. As leader of the church, he is well-known within and outside the Reformed Church. He developed his exceptional knowledge of the Reformed Church and a profound feeling and love for the theology and ethos of the Church at home, where he grew up as one of five brothers who also are ministers of religion. He served as leader of the church on the Commission of the General Synod for 21 years, of which three terms as chair. As chair, he played an extraordinary 
Kerk gespeel om die Kerk in haar teologie en kerkwees binne die Bybels-Reformatoriese teologie te bestendig. Eie aan dié teologie was prof. Dreyer nie 'n geslote leier wat net die status quo wou handhaaf nie - hy was ook'n leier wat die uitdagings van die tyd betyds vir die Kerk raakgesien en aangegryp het. Talle studierapporte wat by kommissies en vergaderings van die Kerk onder sy kennins en insig die lig gesien het, het tot rigtinggewende besluite in die Kerk gelei.

As teoloog aan die een kant en as kerkman aan die ander kant was Theuns Dreyer uitstekend toegerus vir die taak om die leidende rol te speel in die totstandkoming van die Hervormde Teologiese Kollege (HTK) aan die Fakulteit Teologie aan die Universiteit van Pretoria. Vanweë sy dryfkrag en hardwerkendheid is die Kollege stewig gevestig in die Kerk en aan die Universiteit. Dit verskaf aan die Kerk groot sekerheid rakende die kerklike aspek van die teologiese opleiding wat nie by die Fakulteit aandag kan geniet nie. Terselfdertyd lewer die Kollege ' $n$ belangrike bydrae tot die uitbouing van die Bybels-Reformatoriese teologie binne die Hervormde Kerk.

Eers as Hoogleraar in Praktiese Teologie en later as hoof van die HTK het Dreyer derhalwe vir dekades 'n groot en blywende invloed uitgeoefen op predikante van die Kerk en die wyse waarop die Woord van God in die Hervormde Kerk verkondig word. Sy insigte rondom die ontwikkeling van 'n spiritualiteitsbewussyn by voornemende predikante van die Kerk is veral vermeldenswaardig. Hy is uitstekend toegerus om studente van die Kerk op te lei en te begelei vir sekerlik die belangrikste faset van die amp van Dienaar van die Woord, naamlik die prediking. Die meeste van die huidige predikante in die Kerk kan getuig van sy invloed op hulle prediking en pastoraat.

Professor Dreyer het ' $\mathrm{n}$ groot rol gespeel om die visie van die Hervormde Kerk rondom teologiese opleiding duidelike gestalte te gee. Die Hervormde Kerk dank hom en eer hom daarvoor.

Dr Daan J.C. van Wyk Jnr

Voorsitter van die Kommissie van die 69ste Algemene Kerkvergadering van die Nederduitsch Hervormde Kerk van Afrika role in the Church to consolidate the Church in its theological teachings and the unique inner being of the church within the Biblical Reformation theology. Inherent in this theology, Professor Dreyer was not a reticent leader who only wanted to maintain the status quo. As leader, he also saw the challenges of the time and seized these opportunities in good time for the Church. Several study reports that saw the light under his guidance and insight at commissions and synods, led to directional decisions in the Church.

As theologian on the one hand and as clergyman on the other, Theuns Dreyer was well equipped for the task to play a leading role in the establishment of the Reformed Theological College (RTC) at the Faculty of Theology at the University of Pretoria. Due to his driving force and diligence, the College is soundly established in the Church as well as at the University. This provides the Church with great reassurance regarding the ecclesiastical aspects of theological training, which cannot be attended to at the Faculty. Simultaneously, the College contributes to the extension of the Biblical Reformation theology within the Reformed Church.

First as professor of Practical Theology and later as head of the RTC, Professor Dreyer has greatly and lastingly influenced ministers of the Church as well as the way in which the Word of God is preached within the Reformed Church. His insights surrounding the development of the spiritual consciousness of prospective ministers is especially significant. He is extremely well equipped to lead and guide students of the Church in surely the most important facet of the office as Servant of the Word, namely preaching. The majority of current preachers in the Church can testify to the influence he has had on their preaching and pastorate.

Professor Dreyer has played a major role in the vision of the Reformed Church in giving clear direction to theological training. The Reformed Church thanks him and honours him for that.

Dr Daan J.C. van Wyk Jr

Moderator of the 69th General Assembly of the Netherdutch Reformed Church of Africa 